\title{
Weak central coherence is a syndrome of autism spectrum disorder during teacher-learner task instructions
}

\begin{tabular}{|c|c|}
\hline $\begin{array}{l}\text { Authors: } \\
\text { Petronella S. } \\
\text { Janet Condy }\end{array}$ & e Jager ${ }^{1}$ (C) \\
\hline $\begin{array}{l}\text { Affiliations: } \\
{ }^{1} \text { Department } \\
\text { Faculty of Edu } \\
\text { Peninsula Uni } \\
\text { Technology, C } \\
\text { South Africa }\end{array}$ & $\begin{array}{l}\text { fducation, } \\
\text { cation, Cape } \\
\text { versity of } \\
\text { ape Town, }\end{array}$ \\
\hline $\begin{array}{l}\text { 2Literacy Deve } \\
\text { Faculty of Edu } \\
\text { Peninsula Uni } \\
\text { Technology, C } \\
\text { South Africa }\end{array}$ & $\begin{array}{l}\text { lopment, } \\
\text { cation, Cape } \\
\text { jersity of } \\
\text { ape Town, }\end{array}$ \\
\hline $\begin{array}{l}\text { Correspondin } \\
\text { Petronella de } \\
\text { petrozanne@ }\end{array}$ & $\begin{array}{l}\text { g author: } \\
\text { Jager, } \\
\text { smail.com }\end{array}$ \\
\hline $\begin{array}{l}\text { Dates: } \\
\text { Received: } 18 \text { J } \\
\text { Accepted: } 11 \\
\text { Published: } 14\end{array}$ & $\begin{array}{l}\text { une } 2019 \\
\text { Sept. } 2020 \\
\text { Dec. } 2020\end{array}$ \\
\hline $\begin{array}{l}\text { How to cite th } \\
\text { De Jager, P.S, } \\
\text { 2020, 'Weak } \\
\text { coherence is a } \\
\text { autism spectr } \\
\text { during teache } \\
\text { instructions,' } \\
\text { Journal of Chi } \\
\text { Education } 10 \text { ( } \\
\text { https://doi.or } \\
\text { sajce.v10i1.78 }\end{array}$ & $\begin{array}{l}\text { is article: } \\
\text { Condy, J., } \\
\text { entral } \\
\text { syndrome of } \\
\text { um disorder } \\
\text {-learner task } \\
\text { south African } \\
\text { dhood } \\
1), \text { a } 785 \text {. } \\
\text { //10.4102/ } \\
5\end{array}$ \\
\hline $\begin{array}{l}\text { Copyright: } \\
\text { (c) 2020. The } \\
\text { Licensee: AOS } \\
\text { is licensed un } \\
\text { Creative Comr } \\
\text { Attribution Lic }\end{array}$ & $\begin{array}{l}\text { uthors. } \\
\text { S. This work } \\
\text { ler the } \\
\text { nons } \\
\text { ense. }\end{array}$ \\
\hline Read online: & \\
\hline 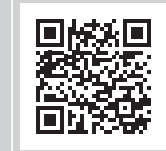 & $\begin{array}{l}\text { Scan this QR } \\
\text { code with your } \\
\text { smart phone or } \\
\text { mobile device } \\
\text { to read online. }\end{array}$ \\
\hline
\end{tabular}

Background: Whilst it is known that weak central coherence (WCC) and global information processing (GIP) challenges contribute to teacher-learner task instruction challenges in learners with autism spectrum disorder (ASD), there are limited data on how teachers in inclusive classrooms respond. Weak central coherence and GIP behaviours manifest in classrooms when learners with ASD focus narrowly on minute detail whilst ignoring teachers' instructions.

Aim: The aim of the study was to describe three case studies of teacher-ASD learner verbal interactions during task instructions in inclusive classrooms.

Setting: Three Grade 3, 9-year-old learners and their teachers were purposively sampled. The learners had been clinically diagnosed with ASD by an independent clinical educational psychologist. The learners' schools, one government inclusive mainstream and one private school, were located in the Western Cape, South Africa.

Methods: An interpretive qualitative case study design was chosen with non-participant observations and individual semi-structured interviews. The data were inductively analysed.

Results: The learners with ASD struggled to comprehend the general classroom discussions and fixated on minute details. This obsessive behaviour was manifested in their inability to appreciate the global perspective of a situation. These tendencies often led to social isolation.

Conclusion: This study highlights a deeper level of misunderstanding during teacher-ASD learner verbal interactions during task instructions. Learners understood the immediate or literal meaning of the verbal instructions, but were persistently pre-occupied with only one part of their teachers' instructions and persevered with smaller details. This study was limited to three learners with ASD, and more studies are required to confirm the results.

Keywords: autism spectrum disorder (ASD); global information processing (GIP); inclusive classrooms; interpretive case study; qualitative study; teacher-ASD learner verbal instructions; weak central coherence (WCC).

\section{Introduction}

Attwood (2007) states that learners with autism spectrum disorder (ASD) only start to feel different when they are in a more formal school environment and extra pressure is put on them to achieve. This feeling of awareness of difference becomes apparent where social interactions and independent problem-solving are expected. Numerous studies have identified weak central coherence (WCC) and global information processing (GIP) as two consistent character trait challenges amongst learners with ASD (Frith 1989; Happé \& Frith 2006; Pina, Flavia \& Patizia 2013). The reason why this study focussed on WCC and GIP challenges was that, according to Happé and Frith (2006:2), the notion of WCC and GIP could address both the strengths and the challenges. When a task requires an individual to extract global meaning from many details, it may pose a challenge to an individual with ASD. Being able to pick out finite details from busy surroundings could be advantageous for these individuals with ASD. Having a fixated and narrow focus of attention may lead to a sense of supremacy rather than a challenge (Happé \& Frith 2006).

In South Africa, it was only after inclusive education (IE) became part of the school system (National Department of Education [NDoE] 2001) that teachers started to accommodate and accept learners with ASD and recognise the unique way that these learners perceive and interact within their classroom environment. Although South African teachers are willing to accommodate 
learners with ASD in their private or government mainstream classes, they often are not adequately trained to accommodate these learners (Equal Education Law Centre [EELC] 2016). They have limited understanding of the unique combination of character traits that these learners possess (Stofile, Green \& Soudien 2018). They state that it is unsurprising that teachers find it difficult to modify their curricula and classroom environments to address these learners' unique learning needs. Creating awareness and understanding amongst teachers of learners with ASD character traits will enable them to make modifications to the curriculum, classroom environments and teaching styles so as to integrate these learners and to allow them to experience optimal learning. It is therefore important for teachers to become cognisant of their learners' difficulties, unique combination of ASD character traits each one possesses and the effect it has on their academic performance. Learners with ASD in school environments must not be viewed as exhibiting a collection of isolated symptoms, but as learners with syndrome-specific strengths and challenges (Happé \& Frith 2006).

Frith (1989), when talking about central cohesion, uses the analogy of trees. She believes that a person with a strong central coherence when looking at a forest of trees would see the forest. A person with WCC would see individual trees. Frith believes that individuals on the autism spectrum have a detail-focussed cognitive style because they '... cannot see the wood from the trees', meaning that they are unable to develop a general understanding of a situation because they are too focussed on the finer details. Jolliffe and Baron-Cohen (1997), O'Riordan et al. (2001) and BaronCohen et al. (2009) agree with Frith (1989) when they state that this excellent attention to detail is only seen in individuals with ASD, yet some lack the cognition to perceive global, cohesive concepts. This results in learners perceiving the world as fragmented, disorganised and as a collection of unrelated details.

When a task requires an individual to extract global meaning from many details, it may pose a problem to an individual with ASD (Happé \& Frith 2006). Being able to pick out extreme detail from surrounding masses could, in some instances, be advantageous for individuals with ASD. Some learners with ASD may experience 'savant skills', which account for advanced abilities to memorise extreme detail, such as in Mathematics, Arts and Music and Electronics (Dawson \& Heaton 2013; Happé \& Booth 2008; Happé \& Frith 2006; Mottron et al. 2013; Wallace 2008).

Whilst there are potential advantages to WCC processing styles (e.g. attention to detail and a narrow focus on attention), Koldewyn et al. (2013) state that there are disadvantages in a world set up for a GIP style of interaction within one's environment (Behrmann et al. 2006; Happé \& Frith1996). Global information processing means '... the ability to integrate piecemeal information into a coherent whole; to grasp the "gist" of a situation' (Happé \& Frith 2006:78). They argue that experiencing GIP challenges often results in individuals with ASD being unable to 'see the big picture', and becoming overly focussed on details, at the expense of a global perspective. This behaviour, according to Happé et al. (2006), can negatively affect an individual's ability to integrate environmental stimuli into a coherent whole.

According to Knott and Dunlop (2007), without an adequate GIP style, individuals with ASD find it difficult to see connections and generalise from one area to another. This challenge occurs, according to Filippello, Marino and Oliva (2013:3), because individuals with ASD process information '... piece by piece, and the information thus obtained is isolated and fragmented'. When learners with ASD focus upon one specific detail only, they can display behaviours of '.. an insistence of sameness of routine, difficulty with categorising and generalising information across environments or audiences' (Brooks 2016:9).

Both the behavioural responses and social adaptation of learners with ASD are influenced by WCC and GIP processing styles. Lawson (2011) indicates that these learners may or may not understand what comes next, not be able to complete a sequence of events, fail to see others' points of view and not adhere to new routines and changes.

The Diagnostic and Statistical Manual of Mental Disorders (DSM-5) (APA 2013:50) criteria for ASD include a fuller description of these WCC and GIP challenges: '... insistence on sameness, inflexible adherence to routines, or ritualised patterns of verbal or non-verbal behaviour ... highly restricted, fixated interests that are abnormal in intensity or focus'. During an investigation into global and local processing in learners with autism, Koldewyn et al. (2013:09) agree that if given a choice, learners with ASD were '... less likely to report global information than their typical developing peers'. They argue, however, that when explicitly instructed to report global information, they performed similarly to learners who were not on the autism spectrum. Because WCC and GIP do not explain all aspects of ASD, Syriopoulou Deli, Varveris and Geronta (2016:114) suggest that individuals with ASD should be considered as a group of learners with a variety of behavioural and social strengths and challenges. This leads to theorists developing a general profile of learners with ASD and may help in better understanding their daily challenges. The latest research on WCC and GIP show that individuals with ASD can process global information as well as typically developed individuals if instructed to do so, but might need more time and show a preference, or advantage and interference from the local level (Booth \& Happé 2018; Spaniol 2018).

The aim of this article was to understand the role of WCC and GIP in three learners, clinically diagnosed with ASD, during teacher-learner verbal interactions in different inclusive classrooms. The three 9-year-old participants were in Grade 3 and were experiencing problems with their teachers' instructions, where they were expected to interact using more problem-solving skills. There is a lack of 
appropriate national and international research conducted in this small niche area; hence, this research can be seen as a pioneer project which will open up similar fields of research for later inquiry.

\section{Research approach}

Three qualitative case studies were conducted within a critical interpretive research paradigm. This collective case study approach allowed the non-participant researcher to immerse herself, from a distance, in the verbal responses of the three learners to familiarise herself with their social worlds, and to look for possible patterns in their lived worlds (De Vos et al. 2011). This approach generated a rich narrative, forming a deeper understanding of the WCC and GIP challenges that the three Grade 3 learners were experiencing when they received task instructions from their teachers.

The criteria for selecting the sample included learners who had been clinically diagnosed with ASD by an independent educational psychologist. The three learners with ASD had recently transitioned into a more formal Grade 3 classroom environment and were either in a mainstream or special school; their parents gave their consent for this study. Eventually, there were three 9-year-old conveniently selected learners. One male participant attended a government inclusive mainstream school (School $\mathrm{R}$ - pseudonym) and two participants (one female and one male) attended the same private school (School P): both schools were located in the Western Cape. The three classroom teachers of the learners formed part of the sample and, in some cases, as explained in Table 1, their support staff members were involved in the observations.

All the teachers involved in this study mentioned that they had no formal experience with learners with ASD, but all had done their own personal research on how to help these learners in their classrooms. Their personal research helped them to appreciate with understanding the importance of implementing strategies that would assist these learners to adapt to new changes, helping the learners find a starting point in an exercise or making sure they knew what was expected of them; for example, not to use idiomatic language or jargon, if possible, and to be sensitive to learners' sensory overload. They were all supported by their principals, with whom they had regular meetings, including the facilitator who had knowledge of how to help the learner she was assigned to.

The researcher collected data by using an extensively pre-planned observation schedule (Appendix 1), making detailed notes of the classroom environments, settings and learner behaviours, which she felt could have a bearing on the observed learners' responses to their teachers' task instructions (Fox \& Bayat 2007). The observations were pre-arranged and approved by the principals and teachers and were conducted in the classrooms from 08:00 h to 14:30 h, and in one session with the classroom facilitator who was assisting the learner. The researcher adopted a nonparticipant observation approach in which she was a passive observer at all times. Learner $\mathrm{T}$ was observed for 5 days, and Learners L and E were each observed for 4 days until data saturation. Two other observation sessions were conducted when the learners were with the librarian and the Physical Education (PE) staff member. In all the observation sessions, the researcher focussed on how the learners reacted to the teacher-learner task instructions, she observed their environment, their interactions within the classroom and their behavioural responses. The teachers' responses to the learners with ASD were also noted. A few disadvantages of using observations for data collection tools were experienced by the researcher. For her to remain a non-participant observer, as unobtrusive as possible (de Vos et al. 2011:3182), and to ensure that she had no influence on the outcome of the learners' behaviour and social interactions (Moon et al. 2016), she either sat on a chair in the doorway of the classroom or observed the learners from a window in the corridor.

Semi-structured interviews were conducted 3 months after the observations and were used to explore the teachers' own understandings, experiences, beliefs and motives, in their own words: how they supported and assisted the learners with ASD in their classrooms. Three interviews were conducted with the teachers in their individual classrooms. Similar probing questions were used to encourage teachers to elaborate upon their answers and enabled them to stay focussed on the topic (Babbie 2013; Hammell, Carpenter \& Dyck 2005). Examples of main and probing questions are included in Appendix 2. Individual, audio-taped interviews were conducted, which permitted face-to-face discussions between the researcher and the teachers (Edwards \& Holland 2013). This procedure had the advantage of

TABLE 1: Details of the participants, teachers and the schools involved in this study.

\begin{tabular}{|c|c|c|c|c|c|}
\hline Learner participants & Gender & Teacher participants & Lessons observed & $\begin{array}{l}\text { Support staff at the time of } \\
\text { the observations }\end{array}$ & School \\
\hline Learner $T$ & Male & Teacher SM & $\begin{array}{l}\text { 1. Mathematics } \\
\text { 2. Life skills -Spring season } \\
\text { 3. Life skills -Library }\end{array}$ & Librarian & $\begin{array}{l}\text { School P-a private school with } \\
25 \text { learners in the class. }\end{array}$ \\
\hline Learner L & Female & Teacher GR & $\begin{array}{l}\text { 1. Afrikaans } \\
\text { 2. English writing activity } \\
\text { 3. Life skills - Physical education }\end{array}$ & $\begin{array}{l}\text { Class facilitator } \\
\text { Physical education teacher }\end{array}$ & \\
\hline Learner $\mathrm{E}$ & Male & Teacher CJ & $\begin{array}{l}\text { 1. Afrikaans } \\
\text { 2. Mathematics } \\
\text { 3. English }\end{array}$ & No support staff & $\begin{array}{l}\text { School R - a government inclusive } \\
\text { mainstream school with } 35 \text { learners } \\
\text { in a class. }\end{array}$ \\
\hline
\end{tabular}


providing social cues: voice and intonation, which could be recorded, whilst body language could be noted on the interview schedule. This nuance added a more in-depth interpretation of the dialogue between the researcher and the teacher (Opdenakker2006).

As this was not a comparative study, each of the three learners' and teachers' observation results (13 in total) and the three audio-recorded interviews were transcribed, sent back to the teachers to check for accuracy and inductively analysed. After reading all the observation data numerous times, the researcher attempted to interpret the learners' behaviours and reactions to teacher-learner task instructions by looking for similarities and differences and colour coding them (Henning, Van Rensburg \& Smith 2007). Three themes emerged within the categories of WCC and GIP: predicting what comes next, not adhering to others' points of view and not adhering to new routine and changes. When analysing the interviews, the researcher identified one theme within the categories of WCC and GIP, implementing secure and structured routines.

To achieve objectivity and trustworthiness in this study, both the observation schedule and interview schedules were pre-tested before the main data were collected. A school principal and an independent educational psychologist offered critical feedback, such as word and sentence clarity and improvements of the structure of the schedule, to allow for more detailed comments about the teachers, additional staff and the participants' reactions to instructions. These suggestions were included in the final schedules with more confidence so as to gain the most trustworthy data (Yin 2009). By using data source triangulation, the researcher was able to compare information collected from the three observations and three interviews (Denzin 2006). All the transcriptions were given back to the teachers to check for accuracy; this member checking ensured credibility and confirmed that the researcher had data that were true and an accurate reflection of the participants' contributions (Babbie \& Mouton 2007). This enabled the researcher to explain more fully the richness and complexity of the processes by which the three participants with ASD made sense of their worlds and interacted socially and behaviourally within their classroom environment (Cohen, Manion \& Morrison 2008).

Ethical clearance was obtained from the university where the researcher was registered (EFEC 6-9/2014), and the Western Cape Education Department provided a letter giving the researcher permission to conduct research in the two schools. Permission was obtained from the two principals, and the three class teachers, a class facilitator, the librarian and the PE teacher gave informed consent. Because the three learners were very young, informed consent letters were obtained from two mothers and one father. The three learners were identified as Learner T, L and E and the teachers were identified as Teachers SM, GR and CJ to maintain anonymity. All participants were assured that strict confidentiality procedures would be adhered to regarding the observation of their children. Assurance was given that their children's identity would not be revealed in the study, and that during the non-participatory observation process their children would not be aware that they were being observed.

This section presents the results for each learner, providing examples of their social cognitive WCC and GIP challenges. Each table provides the sequence of observation events. Three examples from the data have been selected where the learners showed WCC and GIP challenges including an inability to: (1) understand how to complete a task, (2) see another person's point of view during discussions and (3) adhere to new routine and changes during teacher-learner task instructions. After each table there is an interpretation and discussion focussing on the influence of social cognitive and social functioning challenges.

\section{Ethical consideration}

Ethical approval and a letter giving the researcher permission to conduct research in the two schools was given by the Western Cape Education Department (reference: 2013080115170). Permission to conduct the study was also received from the Cape Peninsula University of Technology and the private school principal (reference: EFEC6-9/2014). Because of confidentiality agreement the principal's name and the name of the school were redacted.

\section{Results for Learner T Interpretation and discussion}

Happé and Frith (2006) suggest that individuals with ASD may experience areas of 'superior' processing, or differences in cognitive style, such as WCC and GIP. They state that when these young learners are overly focussed on details at the expense of the global perspective, this over-focussing may adversely affect their ability to integrate environmental stimuli into a coherent whole.

The three examples in Table 2 show that Learner T experienced WCC and GIP challenges; he focussed on specific details that made sense to him alone, as he lacked a global perspective of the content. This caused him to disregard the teacher-learner task instructions. To explore how the above WCC and GIP challenges affected Learner T's behavioural adaptation, the researcher interviewed Teacher SM.

Researcher: Has Learner T always understood what to do next to complete a sequence of events? Is he able to see others' points of view? Does he adhere to new routines and changes?

Because Teacher SM was with Learner $\mathrm{T}$ for the maths, Spring Life Skills lessons and in the library, this is how she responded. 
TABLE 2: Examples of weak central coherence and global information processing challenges experienced by Learner T (Grade3).

\begin{tabular}{|c|c|c|}
\hline $\begin{array}{l}\text { Private school Grade } 3 \\
\text { environment }\end{array}$ & $\begin{array}{l}\text { Observations, August-September } \\
\text { Responses of Learner T }\end{array}$ & $\begin{array}{l}\text { Teacher SM's and the librarian's immediate responses to that } \\
\text { specific behaviour }\end{array}$ \\
\hline \multicolumn{3}{|c|}{ 1. Mathematics: Adding and subtracting method - inability to understand how to complete the underlying sequence of calculations of a mathematics exercise. } \\
\hline \multirow[t]{3}{*}{$\begin{array}{l}\text { (1) Adding and subtracting in } \\
\text { columns.Longitudinal division. } \\
\text { Do sums in own mathematics book. }\end{array}$} & $\begin{array}{l}\text { (2) Learner T's response: } \\
\text { I can do all this adding in my head. I don't need to show you if I } \\
\text { know the answer is correct'. }\end{array}$ & $\begin{array}{l}\text { (3) Teacher SM explains: 'When you do maths in the higher grades you } \\
\text { get marks for showing the method and how you got to the answer'. }\end{array}$ \\
\hline & (4) 'Yes, but you know that I know the answer. It's boring'. & $\begin{array}{l}\text { (5) Teacher SM shows Learner T an example of the method to arrive } \\
\text { at the answer. }\end{array}$ \\
\hline & (6) Kept rocking back and forth showing his frustration. & $\begin{array}{l}\text { (7) Teacher SM responds: } \\
\text { 'I know you know the answer mentally, but now show me on paper } \\
\text { how you derived your answer'. }\end{array}$ \\
\hline \multicolumn{3}{|c|}{ 2. Life skills: Season spring - inability to see Teacher SM's point of view during a discussion on Spring as he had a more literal understanding of 'Spring' } \\
\hline $\begin{array}{l}\text { (1) Teacher SM asked the learners } \\
\text { to bring some cut flowers for } \\
\text { Spring day to celebrate new life } \\
\text { and growth after winter. }\end{array}$ & $\begin{array}{l}\text { (2) The researcher overheard Learner T's comment to Teacher SM: } \\
\text { 'If I bring in picked flowers, it means I am bringing dying flowers. } \\
\text { As you mentioned, is Spring not about new blossoms and flowers?' }\end{array}$ & $\begin{array}{l}\text { (3) Teacher SM's response was: 'If you so wish you can bring a growing } \\
\text { plant in a pot. As long as you are prepared to look after it, water it } \\
\text { every other day when you come to school, to keep it healthy'. }\end{array}$ \\
\hline \multicolumn{3}{|c|}{$\begin{array}{l}\text { 3. Life skills: Library period - Because Learner T had a more global view of sharks, he disagreed with the Librarian, who was not his class teacher and this lesson was not in his } \\
\text { classroom. This created an inability to adhere to a new routine and change during the library period. Teacher SM was in the library and observed the reading period. }\end{array}$} \\
\hline \multirow[t]{2}{*}{$\begin{array}{l}\text { (1) Listened to a story being told } \\
\text { by the librarian in the library. }\end{array}$} & $\begin{array}{l}\text { (2) Learner T expressed his frustration about the story on white } \\
\text { sharks: 'Why do they mention all the shark species when it has to } \\
\text { do with white sharks? The book is incomplete. Sharks are all the } \\
\text { same inside anyway. I am not listening to this anymore'. }\end{array}$ & \multirow[t]{2}{*}{$\begin{array}{l}\text { (3) The librarian stops the story and explains that even though the } \\
\text { book starts off by mentioning sharks in general, the book chooses to } \\
\text { focus only on the white shark. }\end{array}$} \\
\hline & $\begin{array}{l}\text { s own book and disengaged himself } \\
\text { ding. }\end{array}$ & \\
\hline
\end{tabular}

Teacher SM: No, not always. He often got stuck on the finer details that were valid and would not be able to move beyond that and refuse to see the whole picture or main outcome of the discussion or lesson (WCC). He would, for example, during a maths lesson, refuse to adhere to the rules of the lesson as they did not make sense to him (GIP). He would then do the exercise his way and refuse to even consider changing his method of problem solving.

This interview indicates that Learner $\mathrm{T}$ was often rigid and inflexible in his routine (e.g. he knew he could not tolerate the change of the environment and a new teacher [Librarian]): he could not tolerate change (e.g. he could not show his steps in his mathematics work) and could not, or would not, see different points of view for the word 'Spring'. From the evidence collected, it is clear that these behaviours posed a challenge to the teacher-learner task instructions, which inhibited his learning and social interactions (Boyd et al. 2012).

According to the results of the data relating to WCC and GIP, Learner $\mathrm{T}$ reacted as follows to teacher-learner task instructions:

- Learner T found it difficult to understand the underlying steps of a sequence of calculations and therefore refused to comply with the teacher's instructions.

- He could not see others' points of view; he interpreted the meaning of Spring in a literal sense only. He could not see that a separate task like bringing spring flowers to school are related to the theme of 'Spring', and this is a lack of the concept GIP.

- He found it challenging to adhere to routines and changes with a different teacher in a different environment.

It was observed that Learner $\mathrm{T}$ felt that the information that the Librarian was sharing on sharks focussed on white sharks only and was therefore biased. Spaniol (2018) and Booth and Happé (2018) agree that such critique, although valid, may be related to an inability to shift attention from the local to the global level. That means if there is a point of critique bias, the individual with ASD may find it difficult to disengage attention from the local features of stimuli and to shift it to their global properties.

These WCC and GIP challenges constrained Learner T's behavioural adaptation in the following manner. Learner $\mathrm{T}$ often had a valid argument to object to the teachers' instructions, yet he found it difficult to move beyond that argument, follow routines and changes of venue, and show understanding for the views of the discussion held by Teacher SM. Happé and Frith (2006:5) assert that having a fixated and narrow focus of attention, which is a known criterion for experiencing WCC and GIP, may be an advantage rather than a disadvantage. This shows that Learner T experienced WCC and GIP challenges, which directly influenced his behavioural adaptation in Grade 3. Teacher SM and the Librarian implemented secure and structured routines, but at the same time showed patience, understanding and support towards Learner T.

\section{Results for Learner $\mathbf{L}$ Interpretation and discussion}

Learner L was a very clever girl. In the first example (Table 3), she could not understand why she had to do the work again because she disliked doing work she already knew. She knew that the teacher wanted her to complete the task and the facilitator convinced her to do so. She rushed through the task as she wanted to get back to continue making her fairies, which she enjoyed doing. In this example, Learner L did not understand the global perspective, which showed WCC and GIP (DSM-5 2013); it was a 'revision' exercise and not new work. She was able to complete her revision exercise quickly, yet under protest. 
TABLE 3: Examples of weak central coherence and global information processing challenges experienced by Learner $L$ (Grade 3 ).

\begin{tabular}{|c|c|c|}
\hline $\begin{array}{l}\text { Private school Grade } 3 \\
\text { environment }\end{array}$ & $\begin{array}{l}\text { Observations August-September } \\
\text { Responses of Learner L }\end{array}$ & $\begin{array}{l}\text { Teacher GR, facilitator and PE teacher's immediate responses to } \\
\text { that specific behaviour }\end{array}$ \\
\hline \multicolumn{3}{|c|}{ 1. Afrikaans revision exercise - inability to understand the instructions of the teacher and did not understand the global perspective needed to complete the task } \\
\hline \multicolumn{3}{|l|}{$\begin{array}{l}\text { (1) Learners are filling in Afrikaans } \\
\text { words to complete a } \\
\text { comprehension exercise. }\end{array}$} \\
\hline \multirow[t]{2}{*}{$\begin{array}{l}\text { (2) Teacher GR asks the class to } \\
\text { complete an Afrikaans exercise in } \\
\text { their book, as part of revision for } \\
\text { their test. }\end{array}$} & $\begin{array}{l}\text { (3) Learner L's response: 'I refuse. Why do I have to do this work again? I } \\
\text { know all of this and I hate to have to repeat what I know'. }\end{array}$ & $\begin{array}{l}\text { (4) 'I do not know what Afrikaans words everyone is struggling with. } \\
\text { We are all doing revision, so I can make up a list of words for all to } \\
\text { practise'. } \\
\text { The facilitator who sits with Learner } L \text { throughout the day convinces } \\
\text { her to do her work. }\end{array}$ \\
\hline & $\begin{array}{l}\text { (5) Learner L rushes through her work and finishes quickly and correctly. } \\
\text { 'Can I now continue to draw the fairies in my garden?' }\end{array}$ & \\
\hline \multicolumn{3}{|c|}{ 2. English writing exercise - inability to gain a global perspective of the educational task and therefore did not see the big picture } \\
\hline $\begin{array}{l}\text { (1)Teacher GR explains to the class } \\
\text { that they have to write down their } \\
\text { news of the weekend in a few } \\
\text { sentences. }\end{array}$ & $\begin{array}{l}\text { (2) Learner L's response: 'Why must I now write down what I have } \\
\text { already explained in detail during our discussion time? Did you not } \\
\text { listen to what I have had to say the first time?' }\end{array}$ & $\begin{array}{l}\text { (3) Teacher GR's response: 'I did listen to your news contribution, but } \\
\text { now we are doing English writing and therefore you need to write } \\
\text { down your news as well'. }\end{array}$ \\
\hline \multicolumn{3}{|c|}{3 Life skills: Physical education lesson - inability to adhere to a change from classroom routine to outside routine } \\
\hline $\begin{array}{l}\text { partake in an obstacle course. } \\
\text { Learner } L \text { lacks confidence to try. } \\
\text { Teacher needed to provide } \\
\text { support - but she did not. }\end{array}$ & $\begin{array}{l}\text { (4) Learner } L \text { wanders off and gathers some lavender flowers. She } \\
\text { engages in a conversation with the facilitator about the distinct smell of } \\
\text { lavender and its many uses. }\end{array}$ & \\
\hline
\end{tabular}

In the second example (Table 3), Learner L could not understand why the teacher expected her to write down what she had already explained, in detail, to the whole class. She felt that the teacher did not listen to her news contribution; this was an English writing exercise. Learner $\mathrm{L}$ did not see the global perspective of the educational task. She was unable to assimilate information from a new context and showed an obstinate pre-occupation with repeating information that she felt she had already given in detail (Pina et al. 2013). She regarded telling the news and writing the news as two unrelated tasks, without seeing the bigger picture.

In the final example (Table 3), Learner L showed a lack of confidence participating in the physical exercise - she was more intellectual than physical - and this activity scared her, as she was frightened of failing. This experience shows the inability of the PE teacher to adapt her lesson to include Learner L's needs. This is an example of Learner L's refusal to follow her teacher's instructions for doing an exercise, and not seeing the global intentions during the social interactions.

These three examples suggest that Learner L had difficulty with understanding the global perspective of doing the tasks or instructions given to her by her teacher (Baron-Cohen, Leslie \& Frith 1985; Kimhi 2014). She thus understood the information on a surface level.

To provide further understanding of how WCC and the lack of GIP constrained Learner L's ability to achieve teacher-led instructions, the researcher asked Teacher GR the following question during the interview:

Researcher: Does she manage her emotions appropriately to achieve a goal, or complete a task?
Teacher GR: $\quad$ No, not without help. Not from me or from the facilitator. She does not adjust readily to sudden changes (WCC). She has to be convinced the reason why she had to do the task and then she will reluctantly complete it. Learner $\mathrm{L}$ became upset once when I told her that she had to write down her news of the weekend. She only agreed when the facilitator convinced her to complete the task.

Researcher: What are the processes that you used the most to assist her to complete a task?

Teacher GR: $\quad$ I give her the reason why we are doing the task. We were repeating the Afrikaans revision exercise to make sure the whole class understood the work. Then the facilitator made sure she completed the task.

\section{Results for Learner $\mathrm{E}$ Interpretation and discussion}

Although Teacher CJ was not formally trained to work with learners with ASD, she was aware of Learner E's WCC and GIP challenges. An example of how Teacher CJ assisted was evident when she moved Learner E's desk right against her desk where she could regularly and easily interact with him and positively motivate him. The reason for this support was to prevent him from panicking when he could not cope with the teacher-learner task instructions. Having his desk close to Teacher CJ prevented him jumping out of his seat to come to her desk and disrupt the rest of the class. Teacher CJ made sure that Learner $\mathrm{E}$ had all his writing equipment easily available for every lesson near him, preventing him from panicking.

From the examples provided in Table 4, it is clear that Learner $\mathrm{L}$ could not see the big picture and he saw his information in 
TABLE 4: Examples of weak central coherence and global information processing challenges experienced by Learner E (Grade 3).

Government mainstream school Observations August-September Responses of Learner $\mathrm{E}$ Teacher CJ's immediate responses to that specific behaviour Grade 3 environment

1. Afrikaans: inability to understand how to complete a sequence of events during an Afrikaans writing exercise. Inability to construct sentences in Afrikaans writing which was Learner E's Additional Language

(1) Making sentences with words.

Teacher CI writes on the board

some Afrikaans words pertaining
to the 'ui' sound. Response by Learner E: 'But why can't I just use your sentences,

to the 'ui' sound.

own sentences.

(5) Learner E copies the sentences down from the board word for word.

(3) Teacher CJ explains again that he may use the 'ui' word she used, but had to make up his own sentences.

2. Mathematics - inability to understand Teacher CJ's task instructions during a mathematics exercise.

(1) Hexagon and octagon shapes. (2) Learner E kept calling Teacher CJ: 'Ma'am I am stuck and can't do Teacher CJ explains in detail (with this question. What do they want and what does this mean?' visual props) the different shapes and asks the class to complete

and asks the class to complete $\quad$ (4) Response from Learner E: 'But I want to do the first question first, only the questions on the different so I don't get confused. I always start at the beginning'.

their book.

3. English - inability to see the global picture and he could only see the concrete meaning of the discussion of food.

(1) Discussion on traditional foods. (2) Response from Learner E: 'I like to eat what I eat and right now I am Teacher CJ tries to involve Learner not hungry and would like to draw the whale that I started to draw in E in the discussion and asks him Art'. He continues to do his drawing without looking up. what his food preference is.

(6) Teacher CJ leaves him to write the sentences from the board.

(3) Teacher CJ's response: 'As I explained, only do the questions you can do - first. Then we will discuss all the sums afterwards together as a class and learn from each other'.

(5) Teacher $\mathrm{CJ}$ goes and sits at his desk to assist him to do question 1 so he could continue.

(3) Teacher CJ's response. She goes to him and takes his drawing away. 'You can get this back when you have listened and finished your work and only if there is time'.

(5) Teacher CJ's response: 'You are at school now and here to learn about different traditional foods. So please pay attention, even if you do not want to contribute'.

a fragmented and isolated manner (Filippello et al. 2013) and therefore could not understand the relevance of the discussions or other people's points of view.

The researcher interviewed Teacher $\mathrm{CJ}$ to explore how she experienced Learner E's WCC and GIP challenges in her class:

Researcher: Can he keep control of unpleasant feelings like anxiety, frustration?

Teacher CJ: $\quad$ No. He battles with controlling his emotions. Learner $\mathrm{E}$ had trouble transitioning from one task to another, and he did not always adhere to change (WCC). He would switch off and panic and to cope he would just continue what he was doing; for example, working on a drawing that he was busy with. When he did do work, he would insist on doing it his way and would often get stuck and not understand, for example, how to answer the questions in an exercise (GIP).

Researcher: How did you assist him with calming down procedures?

Teacher CJ: I would acknowledge his frustration and would often go and sit next to him and personally explain or assist him in starting or completing his task.

\section{Concluding comments}

The aim of this research project was to describe three case studies of teacher-ASD learner verbal interactions during teacher-learner task instructions in different inclusive classrooms. All three Grade 3 teachers were aware of their learners' WCC and GIP challenges. These challenges were manifested in the following behaviours: atypical, and fixated behaviour that caught their individual attention, with an inability to view relevant detail as a whole. They were persistently pre-occupied with one part of the information and showed a pronounced tendency to focus narrowly upon minute details that attracted them. They were unable to integrate information, often ignoring the teachers' instructions. They found it difficult to adhere to new, unfamiliar routines and changes, and struggled to comprehend the general classroom discussions, and would persevere in their concern with smaller details. This obsessive selfconcerned behaviour was manifested in their overall inability to appreciate the global perspective of a situation. These tendencies often led to social isolation.

In their own ways, the three teachers and support staff acknowledged the importance of developing the confidence of their learners with ASD, and to cope with their WCC and GIP challenges. These learners with ASD required more structure and thoughtful planning in order for them to adapt to change and understand the social and behavioural implications of their learning environments.

Only three learners with ASD in Grade 3 were selected as participants. In some cases, suitable learners were identified; however, the parents were not prepared to grant permission for observations. At the time of the data collection, these learners were attending an inclusive mainstream school and a private school. Learners in Grade 3 manifest with language and cognitive abilities of typical learners yet are only diagnosed as atypical when teacher-led instruction challenges of WCC and GIP become obvious. This study used qualitative analyses of three observations only and three interviews. Because this research project was restricted in its scope and applicability to a small range of Grade 3 learners with ASD, it cannot be applicable in any way to all learners with ASD. The study would have greater transferability if more participants and schools were included. 


\section{Recommendations}

During this research, many teachers reported that they found support structures to be inadequate, which rendered them ill-equipped to adapt their curriculum, and to assist them with teacher-learner instruction tasks when teaching learners with ASD in their South African schools. It is recommended that curriculum differentiation, classroom management and giving instructions should allow for the unique needs of learners with ASD. Although, the teachers observed in this project had no formal training in working with learners with ASD, they developed their own pedagogical approaches to assist them with teacher-learner instruction tasks and would be well suited to head up teams of support to assist teachers in government and private schools during in-service training or workshops. Further research is required in terms of the larger theoretical issues, which are prompted by this initial empirical research.

\section{Acknowledgements}

This article is based on the authors' PhD thesis of which the secondary author was the main supervisor.

\section{Competing interests}

There are no competing interests in this article.

\section{Authors' contributions}

P.S.d.J was responsible for the research and writing of the article. J.C. was the supervisor and provided guidance and support and edited the article for final approval before submission.

\section{Funding information}

This research received no specific grant from any funding agency in the public, commercial or not-for-profit sectors.

\section{Data availability statement}

Data sharing is not applicable to this article as no new data were created or analysed in this study.

\section{Disclaimer}

The views expressed in this article are the authors' own. The content of the article have nothing to do with the official position of the university.

\section{References}

American Psychiatric Association (APA), 2013, Diagnostic and statistical manual of mental disorders: DSM-5, American Psychiatric Association, Washington, DC.

Attwood, T., 2007, The complete guide to Asperger's syndrome, Jessica Kingsley Publishers, London.

Babbie, E., 2013, The practice of social research, Wadsworth Cengage Learning London.

Babbie, E. \& Mouton, J., 2001, The practice of social research, 8th edn., Oxford University Press, Cape Town.
Baron-Cohen, S., Ashwin, E., Ashwin, C., Tavassoli, T. \& Chakrabati, B., 2009, 'Talent in autism: Hyper-systemizing hyper-attention to detail and sensory hypersensitivity', Philosophical Transactions of the Royal Society Biological Sciences 364, 1337-1383. https://doi.org/10.1098/rstb.2008.0337

Baron-Cohen, S., Leslie, A.M. \& Frith, U., 1985, 'Does the autistic child have a "theory of mind"?', Cognition Elsevier 21(1), 37-46. https://doi.org/10.1016/00100277(85)90022-8

Behrmann, M., Avidan, G., Leonard, G.L., Kimchi, R., Luna, B., Humphreys, K. et al., 2006, 'Configurable processing in autism and its relationship to face processing', Neuropsychologia 44(1), 110-129. https://doi.org/10.1016/j. processing', Neuropsychologia

Booth, R.D. \& Happé, F.G., 2018, 'Evidence of reduced global processing in autism spectrum disorder', Journal of Autism and Developmental Disorders 48(4), $1397-$ 1408. https://doi.org/10.1007/s10803-016-2724-6

Boyd, B.A., McDonough, S.G. \& Bodfish, J.W., 2012, 'Evidence-based behavioural interventions for repetitive behaviours in autism', Journal of Autism and Developmental Disorders 42(6), 1236-1248. https://doi.org/10.1007/s10803011-1284-z

Brooks, L.P., 2016, 'Effectiveness of a social thinking curriculum on social competence of students with autism spectrum disorders', PhD thesis, Georgia State University, Atlanta, GA.

Cohen, L., Manion, L. \& Morrison, K., 2008, Research methods in education, 6th edn., Abingdon, Routledge.

Denzin, N., 2006, Sociological methods: A sourcebook, N.J, Aldine Transaction, New Brunswick.

De Vos, A.S., Strydom, H., Fouché, C.B. \& Delport, C.S.L., 2011, Research at grassroots: For the social sciences and human service professions, 4th edn., Van Schaik Publishers, Pretoria.

Edwards, R. \& Holland, J., 2013, What is qualitative interviewing?, Bloomsbury Publishing, London.

Equal Education Law Centre (EELC), 2016, Inclusive education, Learners with learning barriers, The right to an equal and quality education, viewed 22 October 2017, from http://eelawcentre.org.za/wp-content/uploads/2017/05/eelc-annual-report-2016. pdf

Filippello, P., Marino, F. \& Oliva, P., 2013, 'Relationship between weak central coherence and mental states understanding in learners with autism and in learners with ADHD', Mediterranean Journal of Clinical Psychology 1(1), 1-18.

Fox, W. \& Bayat, M.S., 2007, A guide to managing research, Juta and Co. Ltd, Cape Town.

Frith, U., 1989, Explaining the enigma, Blackwell Publishers, Oxford.

Hammell, K.W., Carpenter, C. \& Dyck, I., 2005, Using qualitative research: A practical introduction for occupational and physical therapists, Elsevier Publishers, London.

Happé, F. \& Booth, R.D., 2008, 'The power of the positive: Revisiting weak coherence in autism spectrum disorders', Quarterly Journal of Experimental Psychology 61(1), 50-63. https://doi.org/10.1080/17470210701508731

Happé, F., Booth, R., Charlton, R. \& Hughes, C., 2006, 'Executive function deficits in autism spectrum disorders and attention-deficit/hyperactivity disorder: Examining profiles across domains and ages', Brain and Cognition 61(1), 25-39. https://doi. org/10.1016/j.bandc.2006.03.004

Happé, F. \& Frith, U., 1996, 'The neuropsychology of autism', A Journal of Neurology 119(4), 1377-1400. https://doi.org/10.1093/brain/119.4.1377

Happé, F. \& Frith, U., 2006, 'The weak coherence account: Detail-focused cognitive style in autism spectrum disorders', Journal of Autism and Developmental Disorders 36(1), 5-25. https://doi.org/10.1007/s10803-005-0039-0

Henning, E., Van Rensburg, W. \& Smith, B., 2007, Finding your way in qualitative research, Van Schaik, Pretoria.

Jolliffe, T. \& Baron-Cohen, S., 1997, 'Are people with autism or Asperger's syndrome faster than normal on the embedded figures task?', Journal of Child Psychology and Psychiatry 38(5), 527-534. https://doi.org/10.1111/j.1469-7610.1997. tb01539.x

Kimhi, Y., 2014, 'Theory of mind abilities and deficits in autism spectrum disorders', Topics in Language Disorders 34(4), 329-343. https://doi.org/10.1097/TLD. 0000000000000033

Knott, F. \& Dunlop, A.W., 2007, Developing social interaction and understanding A resource for working with learners and young people with autism, National Autistic Society, London.

Koldewyn, K., Jiang, Y., Weigelt, S. \& Kanwisher, N., 2013, 'Global/local processing in autism: Not a disability, but a disinclination', Journal of Autism and Developmenta Disorders 43(10), 2329-2340. https://doi.org/10.1007/s10803-013-1777-z

Lawson, W., 2011, The passionate mind: How people with autism learn, Jessica Kinsley Publishers, London.

O'Riordan, M. Plaisted, K Driver, J \& Baron-Cohen, S, 2001, 'Superior visual search in autism', Journal for Experimental Psychology: Human Perception and Performance 27(3), 719-730. https://doi.org/10.1037/0096-1523.27.3.719

Moon, K., Brewer, T., Adams, V.M., Januchowski-Hartley, S.R. \& Blackman, D., 2016 'Developing guidelines to improve qualitative social science publishing in conservation journals', Ecology \& Society 21(3), 17, viewed 09 November 2017, from https://doi.org/10.5751/ES- 08663-210317.

Mottron, L., Bouvet, L., Bonnel, A., Samson, F., Burack, J.A., Dawson, M. et al., 2013 'Vertical mapping in the development of exceptional autistic abilities', Journal in Neuroscience and Bio-behavioural Reviews 37(2), 209-228. 
Opdenakker, R.J.G., 2006, 'Advantages and disadvantages of four interview techniques in qualitative research', Forum: Qualitative Social Research 7(4), a11, viewed
09 November 2017, from http://nbn-resolving.de/urn:nbn:de:0114-fas0604118.

Pina, F., Flavia, M. \& Patrizia, O., 2013, 'Relationship between weak central coherence and mental states understanding in learners with autism and in learners with ADHD', Mediterranean Journal of Clinical Psychology 1(1), 1-19.

South Africa. National Department of Education, 2001, Education white paper 6 : Special needs education: Building an inclusive education and training system Government Printer, Pretoria.

Spaniol, M.M., 2018, 'Attentional atypicalities in autism spectrum disorder and the broader autism phenotype', Cadernos de Pós-Graduação em Distúrbios do Desenvolvimento 18(1), 117-147. https://doi.org/10.5935/cadernosdisturbios. v18n1p117-147
Stofile, S., Green, L. \& Soudien, C., 2018, Inclusive education in South Africa, in P. Engelbrecht \& L. Green, (eds.), Responding to the challenges of inclusive education in southern Africa, pp. 75-88, 2nd edn., Van Schaik, Pretoria.

Syriopoulou Deli, C.K., Varveris, A. \& Geronta, A., 2016, 'Application of theory of mind, theory of executive functions and weak central coherence theory to individuals with ASD', Journal of Educational and Developmental Psychology 7(1), 102-122. https://doi.org/10.5539/jedp.v7n1p102

Wallace, G.L., 2008, 'Neuropsychological studies of savant skills: Can they inform neuroscience of giftedness?', Roeper Review 30(4), 246-246. https://doi. org/10.1080/02783190802363901

Yin, R.K., 2009, Case study research: Design and methods, 4th edn., Sage, Thousand Oaks, CA. 


\section{Appendix 1}

\section{Observation sheet for learners in Grade 3}

Observe learners behavioural responses in the learning environment to identify what behavioural adaptation challenges he or she experiences. Observe positive behavioural responses (verbal, physical comments from the learner, as well as positive response from teacher and additional staff) - observe the finer detail of the learners' comments.

To focus on events in the following manner:

1. Subject description - Write down the subject: life skills, English, Afrikaans, social sciences and maths, etc.;

2. Environmental setting - Give descriptions of external factors: venue, props and new additional information;

3. Learners' responses - Look at learners' behavioural responses in the learning environment to identify behavioural adaptation challenges (verbal and physical responses); and

4. Second party responses - responses from peers (positive and negative responses);

5. Teacher or additional staff immediate responses and intervention strategies;

6. Learners' positive responses - verbal and non-verbal; and

7. Teachers and additional staffs' positive responses and interventions strategies.

\begin{tabular}{|c|c|c|}
\hline Theory of mind & Response challenges & Positive comment \\
\hline \multirow{2}{*}{$\begin{array}{l}\text { Recognising and understanding of thoughts } \\
\text { beliefs, desires and intentions of others } \\
\text { (Baron-Cohen et al. 1985) }\end{array}$} & $\begin{array}{l}\text { Not understanding intentions of others Improper } \\
\text { reciprocity skills Cannot understand abstract ideas }\end{array}$ & \multirow[t]{2}{*}{$\begin{array}{l}\text { Although they have challenges with social imagination, it } \\
\text { does not mean they do not have imagination. }\end{array}$} \\
\hline & \multirow{3}{*}{ Cannot do social imaginary play } & \\
\hline Social imagination & & Positive response \\
\hline $\begin{array}{l}\text { The capacity to think about and predict the } \\
\text { consequences of one's actions and oneself and } \\
\text { other people (Wing 1979) }\end{array}$ & & $\begin{array}{l}\text { Often involved in own imaginary play when focussed on } \\
\text { interest. }\end{array}$ \\
\hline Central coherence & Response challenges & Positive comment \\
\hline $\begin{array}{l}\text { Ability to derive overall meaning form a mass of } \\
\text { detail }\end{array}$ & $\begin{array}{l}\text { Not understanding what comes next, to complete } \\
\text { a sequence of events }\end{array}$ & $\begin{array}{l}\text { Although challenges with general understanding, they } \\
\text { show understanding of finer details of significance. }\end{array}$ \\
\hline Weak central coherence & \multirow{4}{*}{$\begin{array}{l}\text { Not seeing others point of view Not adhering to } \\
\text { new routines and changes }\end{array}$} & Positive response \\
\hline $\begin{array}{l}\text { Heightened focus on 'detail' rather than the } \\
\text { 'whole' (Frith 1989) }\end{array}$ & & $\begin{array}{l}\text { Ability to see finer detail in a situation that often can be } \\
\text { overlooked. }\end{array}$ \\
\hline \multicolumn{2}{|l|}{ Global information processing } & \\
\hline $\begin{array}{l}\text { The ability to integrate piecemeal information into } \\
\text { a coherent whole; to grasp the 'gist' of a situation } \\
\text { (Happé \& Frith 2006) }\end{array}$ & & \\
\hline
\end{tabular}

\begin{tabular}{|c|c|c|}
\hline Executive function & Challenging skills & Positive comment \\
\hline $\begin{array}{l}\text { Brain-based skills that are required for humans } \\
\text { to perform a task or interact appropriately } \\
\text { (Dawson \& Guare 20120; Hill 2004) }\end{array}$ & $\begin{array}{l}\text { Organising and planning } \\
\text { Task inhibition } \\
\text { Goal-directed } \\
\text { Sustained attention }\end{array}$ & $\begin{array}{l}\text { Although learners with ASD experience EF challenges, } \\
\text { they do not show the lack of these skills when focussing } \\
\text { on own interest. }\end{array}$ \\
\hline Social interaction & Response challenges & Positive response \\
\hline $\begin{array}{l}\text { Appropriate personal and group interaction in } \\
\text { the social environment }\end{array}$ & $\begin{array}{l}\text { Response inhibition } \\
\text { Emotional control } \\
\text { Inappropriate social behavioural responses }\end{array}$ & $\begin{array}{l}\text { Often very focussed, organised and show sustained } \\
\text { attention to complete a task of specific interest. }\end{array}$ \\
\hline
\end{tabular}

ASD, autism spectrum disorder.

\begin{tabular}{|c|c|c|}
\hline Sensory processing & Challenging skills & Positive comment \\
\hline Hyper-sensitivity, when stimuli feel too intense & $\begin{array}{l}\text { Challenges with hypo- and hyper-sensitivity } \\
\text { sensesTactile touchVisual - sight }\end{array}$ & \multirow{3}{*}{$\begin{array}{l}\text { Although they have challenges with hypo- and hyper-sensitivity } \\
\text { of senses, some learners with ASD can experience superior and } \\
\text { heighted sense reactions that can be seen as positive. }\end{array}$} \\
\hline \multirow[t]{2}{*}{$\begin{array}{l}\text { Hypo-sensitivity when young learners under- } \\
\text { respond to stimuli (Wing 1998) }\end{array}$} & $\begin{array}{l}\text { Auditory - hearingVestibular - balance and } \\
\text { movement }\end{array}$ & \\
\hline & Proprioceptive - muscle reaction & \\
\hline Social communication & Response challenges & Positive response \\
\hline \multirow[t]{2}{*}{$\begin{array}{l}\text { Verbal and non-verbal behaviours people use to } \\
\text { influence social situations (Timler, Vogler-Eiias \& } \\
\text { McGil 2007) }\end{array}$} & $\begin{array}{l}\text { Inappropriate social non-verbal and verbal } \\
\text { communication Inability to adapt to change of social } \\
\text { setting }\end{array}$ & $\begin{array}{l}\text { Some learners may experience focussed sensory experiences, for } \\
\text { example in visual and auditory, that can be of benefit to a } \\
\text { situation. }\end{array}$ \\
\hline & $\begin{array}{l}\text { Inability to express thoughts in socially acceptable } \\
\text { manner }\end{array}$ & \\
\hline
\end{tabular}

ASD, autism spectrum disorder. 


\begin{tabular}{|lllll}
\hline Learner & School & Date & Day & Pag no. \\
Subject & Environmental setting & Learner's responses & $\begin{array}{l}\text { Teachers' immediate responses } \\
\text { (intervention strategies) }\end{array}$ \\
& Description of external factors & Behavioural adaptation challenges & Additional positive comments & Class teachers' responses \\
(relevant information) & Verbal responses & (intervention strategies) & \\
& Venues & Physical responses of the learner & & \\
& Props and new additional & & & \\
& information & & \\
\hline
\end{tabular}

\section{Appendix 2}

\section{One example of a main and probing interview question}

\begin{tabular}{|c|c|c|c|c|}
\hline Emotional control & Yes & No & Inconsistent & Assistance and support \\
\hline Main question & & & & Main question \\
\hline $\begin{array}{l}\text { Does he or she manage his or her emotions } \\
\text { appropriately to achieve a goal, complete a task? }\end{array}$ & & & & \multirow{2}{*}{$\begin{array}{l}\text { What adjustments did you have to make to assist him or her in controlling his } \\
\text { emotions in a socially acceptable way and using appropriate social interaction } \\
\text { during times of confusion and misunderstanding? }\end{array}$} \\
\hline Probing questions & & & & \\
\hline \multirow{2}{*}{$\begin{array}{l}\text { Can he or she keep control of unpleasant feelings like } \\
\text { anxiety, frustration and disappointments? }\end{array}$} & & & & \multirow{2}{*}{$\begin{array}{l}\text { Probing questions } \\
\text { How have you assisted him or her in developing coping skills for next year? }\end{array}$} \\
\hline & & & & \\
\hline $\begin{array}{l}\text { Can he or she join into a conversation without getting } \\
\text { overly excited or emotional? }\end{array}$ & & & & $\begin{array}{l}\text { How did you assist him or her to express feelings in a more socially acceptable } \\
\text { way? }\end{array}$ \\
\hline Can he or she tolerate criticism from adults? & & & & What are the processes that you used the most? \\
\hline \multirow{2}{*}{$\begin{array}{l}\text { Can he or she deal with perceived 'unfairness' without } \\
\text { getting overly upset? }\end{array}$} & & & & How did you assist his or her with calming down procedures? \\
\hline & & & & \multirow[t]{2}{*}{ How did you assist with adjusting behaviour when overly excited or upset? } \\
\hline $\begin{array}{l}\text { Can he or she adjust behaviour quickly after physical } \\
\text { activity or stimulating situations? }\end{array}$ & & & & \\
\hline
\end{tabular}

